\title{
Chapter Three \\ Eyewitnesses to Heroism: Emmanuil Kazakevich and Vera Panova
}

\author{
Here everyone is a hero, just living here \\ is already heroism. \\ Здесь все герои, жить здесь уже \\ героизм.
}

-Emmanuil Kazakevich

Though it's odd, you're never more alive than when you're almost dead.

-Tim O’Brien

War gave new life to Soviet literature and breathed fresh air into socialist realism. During the four years of war, more than 150 major novellas and novels about the war were published in Russian. ${ }^{1}$ War literature thrived both during the war and afterward. In effect, the Second World War generated the material for which Soviet writers had been searching.

The best war writing often comes from those who witness the events. They come in two kinds: the observer-often a journalist-and the participant, a soldier or someone who otherwise contributes to the war effort. This is true not only of Soviet fiction: think of Leo Tolstoy, but also Ernest Hemingway and Tim O'Brien. The main writers of the Soviet war experience also fall into these two categories: Alexander Tvardovsky, Ilya Ehrenburg, Konstantin Simonov, and Vasily Grossman were journalists working in and among Soviet battalions for such newspapers as the Red Army's Krasnaya Zvezda, Izvestiya, or Pravda, while writers and poets like Boris Slutsky, Viktor Nekrasov, and Bulat Okudzhava served themselves, as soldiers, reconnaissance men, sappers, etc. ${ }^{2}$ We have looked closely at Tvardovsky in the previous chapter. In this chapter we will consider Vera Panova, a

1 P. M. Toper, Radi zhizni na zemle: Literatura $i$ voina. Traditsii. Resheniia. Geroi, 3rd ed. (Moscow: Sovetskii pisatel', 1985), 372.

2 For more on writers in wartime see Anna Krylova, "Healers of Wounded Souls': The Crisis of Private Life in Soviet Literature, 1944-1946," Journal of Modern History 73.1 (2001): 307-331, esp. 313-314 and 330. See also her Neither Erased Nor Remembered: Soviet "Women Combatants" and Cultural Strategies of Forgetting in Soviet Russia, 1940s-1980s (New York: Bergahn Books, 2010). 
journalist-turned-participant who travelled the rails with a hospital train, and Emmanuil Kazakevich, a poet-turned-reconnaisance man who wrote fiction immediately following the war. Both of these writers memorized the faces, events, and experiences of those around them to reproduce at war's end in narratives that evoked the struggles and individual suffering of World War II. ${ }^{3}$

Participants who become writers fulfill a double function: they both contribute to the war effort and chronicle the war. They witness, and they create meaning out of their experiences and observations for their own and future generations. Gorky had chided Furmanov for writing like a witness rather than an artist, but as we saw in chapter 1, the witness function was essential for creating the feeling of authenticity that Soviet readers sought. ${ }^{4}$

In the Soviet Union, journalists worked in the service of the state. But for participants, there was a double obligation: they may have worked for the state, but they also had personal stock in being truthful to what they saw and did, to their own experiences in war and to those of their comrades. There were thus two levels of truth, the official and the personal. These authors needed to figure out a way to tell their own truths within the strictures of socialist realism and official doctrine. Literaturnaya gazeta's August 1941 editorial on "the place of the writer in the Fatherland War," quoted in a previous chapter, was only one of many official Soviet calls for service to the country. These participants answered that call and their internal call to testify. In their fiction, writers presented actual conflicts and ethical crises in the context of everyday life, and they strove to do so within an ideological framework.

As we saw in the last chapter, Tvardovsky's immensely popular Vasily Tyorkin was written and read during the war. In this chapter, we look at Kazakevich's The Star (Zvezda) and Panova's The Train Companions (Sputniki), both written in the wake of the war and published in 1946. These works draw their power from the negotiation of the ambiguous wartime boundaries between journalism and fiction, between facts and myths, between the real and the true. Firmly grounded in the byt of wartime experience, both narra-

3 Grossman's war writings have been collected and translated into English by Antony Beevor and Luba Vinogradova. See A Writer at War: Vasily Grossman with the Red Army, 1941-1945 (New York: Pantheon, 2005).

4 Tolstoy wrote both as a witness and as an artist; compare his work on Sevastopol to War and Peace. 
tives choose to highlight the collective over the individual, the "we" working together to get the job done on the front and in the rear over the individual hero completing heroic feats.

\section{Witnesses to War}

Kazakevich and Panova make an interesting pair. Both came to their fiction about war from journalism. Both won Stalin Prizes for their efforts, and both achieved their success from what we might think of as the margins of Soviet society.

Kazakevich was a Jew-one of the few Soviet writers to emerge from Birobidzhan, the capital of Stalin's Jewish Autonomous Oblast in the Far East near the Chinese border; and Panova was a woman writing about perhaps the world's most quintessentially male activity. Both were witnesses to heroism and cowardice, to triumph and pain and death, and both chronicled those scenes for their fellow Soviet citizens.

Emmanuil Kazakevich (1913-1962) had a peripatetic career. He worked variously as a cultural official, kolkhoz director, journalist, and theater director. He relocated to Moscow in 1938 and during World War II served as a reconnaissance man. Wanting to see action at the front and to store up impressions as literary material, Kazakevich wrote to a fellow soldier, "This is not the pose of a daring person or the naked words of a braggart. This is a question of my burning desire and, if you want, of my future literary life. That's why I'm heading out. . ." Immediately at war's end he produced the novella The Star based on his experiences, ${ }^{6}$ and only a few years later, in 1949, The Star was adapted as a film for the first time, and directed by Alexander Ivanov.

For decades The Star was an integral part of the Russian school curriculum, in great part because it demonstrated the proper attitude toward the homeland and featured the components of love, comradeship, and patriotism in just the right doses, perfect for forming young minds. These components enabled Kazakevich's story to be read by several generations as an inspira-

5 Voennyi put' E.G. Kazakevicha, 436, quoted in N. Eidinova, "Negasnushchii svet Zvezdy (O povesti Em. Kazakevicha)," in Slova, prishedshie iz boia, ed. A. G. Kogan (Moscow: Kniga, 1980), 37.

6 I will be quoting from E. Kazakevich, Zvezda: povest', in Velikaia otechestvennaia, ed. V. Kozhevnikov, K. Simonov, and A. Surkov (Moscow: Khudozhestvennaia literatura, 1966), 7-80. 
tional text about the Great Fatherland War, in which boys from different ethnic backgrounds come together to fight the hated foe.

The story was not too idealized, though: according to one critic, The Star "avoids heroic embellishments," instead offering an engrossing depiction of complex and imperfect relations between soldiers who make mistakes, have some successes, and perish in the end. This ending, in which the entire group dies, leaving the lone female character to mourn, offers a "human element" but also reiterates the trope of the sacrificial warrior from Furmanov's Chapaev. The military feat, as appropriate in the rhetoric of podvig, is accomplished.

Vera Panova (1905-1973), a dramatist and novelist who was born in Central Russia, worked off and on as a radio and newspaper journalist and as a copy editor before and during the war, and it was in her role as a journalist that she ended up in the war zone. Initially her assignment had her investigating a military hospital train to produce a propaganda piece about it. As she did this, she met and interviewed dozens of military personnel and got to know their stories. In the end, she finished her piece on the hospital train too late in the war to have it contribute to the war effort. But she also transformed the characters she met and the experiences she had on the train into fiction for her novel The Train Companions.

Kazakevich and Panova remained successful mainstream writers until their deaths in 1962 and 1973, respectively. Forgotten as the Soviet era waned, Kazakevich lost his foothold in the school curriculum, and his works languished after the breakup of the Soviet Union. Panova remained a middlebrow Soviet writer, winning popularity with many readers because of the empathy she expressed for the everyday lives of her characters, and only in the last versions of her memoirs, published for the one hundredth anniversary of her birth, did her personal struggles with the Soviet regime come out in full. ${ }^{8}$ Both novellas have recently been reissued and are again enjoying popularity in post-Soviet Russia.

7 See Wolfgang Kasack, Dictionary of Russian Literature since 1917, translated by Maria Carlson and Jane T. Hedges (New York: Columbia University Press, 1988), 164.

8 See Adele Barker, "V. F. Panova," in Dictionary of Russian Women Writers, ed. Marina Ledkovsky, Charlotte Rosenthal, and Mary Zirin (Westport, CT: Greenwood Press, 1994), 483-485. Panova's memoirs, O moei zhizni, knigakh i chitateliakh, were first published in the journal Neva 4 (1973). See also Xenia Gasiorowska, Women in Soviet Fiction, 1917-1964 (Madison: University of Wisconsin Press, 1968). The young Sergei Dovlatov, who will feature in chapter 6 below, worked for a time as Panovas secretary. 
In The Star's martyred hero Travkin, we can see the continuing evolution of the Chapaev template in war fiction. Kazakevich's Travkin, like Tvardovsky's Tyorkin, is smarter and more selfless than the original, but like Chapaev he is doomed to perish behind enemy lines with no hope of personal happiness. Panova's novel is an ensemble piece, with many featured characters, but her central protagonist is the party boss Danilov, a facilitator who keeps her train moving, and in so doing follows the path of Furmanov's Klychkov. Danilov shares characteristics with Chapaev and Tyorkin, including his roots in a simple peasant family, but his role in wartime as a party worker and bureaucrat creates a parallel with Klychkov. These central protagonists do not feature as heroes per se for the novellas; they are more important as a part of the whole, as leaders within the collective. In these narratives, for Panova and Kazakevich, the war effort was about the "we."

\section{Kazakevich and The Star}

Kazakevich was one of Tvardovsky's closest friends after the war. ${ }^{9}$ Writing Kazakevich's obituary in 1962, Tvardovsky noted:

The appearance of his novella [The Star] marked the arrival in Soviet Russian literature of a great, completely original and striking talent and - more than that - a new step in assimilating the material of World War II.

This novella has become one of the best works of Soviet literature. Its qualities - unusually polished prose, the symmetry of its parts and completeness of the whole, the musical rhyming of the beginning with the ending, along with the deep lyricism and dramatic nature of the plot, the unforgettable vividness of the heroes and their human charmkeep it from losing its power to impact readers, even years later....

I would find it difficult to identify a work by any of today's young prose writers, who are writing at the most auspicious time imaginable for literature, which would come anywhere near the depth of plot and perfection of form of Kazakevich's The Star. ${ }^{10}$

9 Note that Kazakevich also wrote a biographical book about Lenin, The Blue Notebook, about which Nikolai Pogodin, Soviet playwright and himself a winner of the Lenin prize, wrote, "A talented pen has given us a true literary work in which Lenin's mighty heart lives, burns and beats." Kazakevich was a two-time Stalin prizewinner, in 1948 for Star and in 1950 for Spring on the Oder.

10 Quoted in Margarita Aliger, “Tropinka vo rzhi," Vospominaniia ob Aleksandre Tvardovskom: sbornik, 2nd ed. (Moscow: Sovetskii pisatel', 1982), 403. 
Obituaries lend themselves to exaggerated encomiums, but if we take Tvardovsky at his word, we get some sense of the significance this book had for the postwar Soviet generation.

As Tvardovsky also commented in the obituary, this novella of reconnaissance units during the war came directly out of Kazakevich's personal experience, and its stylistic perfection in prose seems all the more remarkable considering Kazakevich's pre-war background-as a poet who wrote in Yiddish. But Kazakevich went to war to become a writer, and his experiences there changed him profoundly. As he stated upon the conclusion of the war, "It seems to me that I have experienced everything: suffering, and deprivation, and horror at the sight of depravity, and exultation at the sight of nobility-everything war contains within it."11

Kazakevich wrote a number of narratives set in wartime, including The Star, Two in the Steppe (1948), Spring on the Oder (1949), and The Heart of a Friend (1953), but The Star was by far the most popular and successful, earning him wide acclaim and more than fifty editions in many languages, as well as the Stalin Prize, as already mentioned. According to his friend and colleague Margarita Aliger, later works were criticized for too much "humane pathos," and despite the Thaw, his essay from the late 1950s on Lenin and Stalin-entitled "Genius and Villainy," after Pushkin's formulation-remained unpublishable, even in Tvardovsky's Novyi Mir, until the glasnost period in the late $1980 \mathrm{s.}^{12}$

In The Star, a short narrative filled with descriptive language and intense emotions, Kazakevich draws on commonplace Soviet war themes as well as conventional boyhood stories of adventure and exploration. For example, the youngest of Kazakevich's characters, Golub, trembles with ecstasy as he somehow merges his hatred of Germans (who had hung his father) and his recollections of "romantic stories of trappers, Indians, and daring travelers" (Zvezda, 54). Dashes across meadows and slow, even marches along ridges-these are the movements of the reconnaissance team; and when they go behind enemy lines, readers hold their breath, hoping against hope for a successful mission.

Hatred and ecstasy, fear and daring-the intense energy of life behind enemy lines is harnessed to the mission before the soldiers, the doctrinally

11 Quoted in L. A. Gladkovskaia, "Emmanuil Kazakevich,” 5-24 in Emmanuil Kazakevich, Sobranie sochinenii, vol. 1 of 3 (Moscow: Khudozhestvennaia literatura, 1985), 7. 
required successful mission, which involved a feat and sacrifice. Kazakevich participates in the rhetoric of podvig and demonstrates in The Star the strength of the tiny reconnaissance unit against an enormous elite Nazi tank division. His novella highlights the protagonist, Lieutenant Travkin, only to show that the individual merges with the "we" in the service of a greater cause. Part of what makes the narrative so exciting is the visual quality of the prose, a quality that served to turn The Star into a successful film in the immediate postwar era with Ivanov's 1949 effort, as well as in the recent past, with Alexander Lebedev's remake in 2002.

\section{Volodya Travkin as Heroic Leader}

Let us take a closer look at several of the characters from Kazakevich's novella, beginning with the central hero. Travkin strikes the reader as the perfect Soviet officer. The narrator introduces him as "a modest, serious, loyal man who always walks in death's line of sight, closer to death than anyone. . ." (16). The head of the reconnaissance unit, Travkin surprises some of his men with his selflessness, his dedication to his duties, indeed, what the narrator at one point calls a "fanaticism in fulfilling his duty": "Not to think of his own advantage, but only about his cause - that's how Travkin had been raised ... [and he was] ready to give up his life for it" (37-38).

This cause-rendered more generally as delo-is in wartime very clear, much clearer than it was for Turgenev's and Dostoevsky's characters in imperial Russia, who had struggled with the dichotomy of word versus deed, slovo and delo. Representative of the New Soviet Man, Travkin and his kind were quick to recognize the nature of the deed, and they moved to act with a sure-footedness that would have been the envy of their nineteenth-century predecessors. $^{13}$

Travkin's leadership style mimics that of Chapaev-always out in front, despite what the manual says about protecting the head of the unit. The Star centers around Travkin's unit of military scouts, who penetrate behind enemy lines to discover a huge SS offensive in the making. This discovery and the imperative to stop the offensive provide the primary plot of the novella.

13 Turgenev planted his character Rudin (in the 1859 novel of that name) on the barricades of Paris in 1848, feeling that he needed to make him act after all his speechifying in the Russian country "nest." Where better to act than in a war zone, even if that war was taking place on foreign soil? 
A secondary plotline concerns Katya, the radio operator, who falls in love with Travkin. In wartime, Russian soldiers were not to be distracted by women or thoughts of love, and Travkin is no exception, but Kazakevich uses Katya to characterize the leader further, from a woman's point of view:

In her mind's eye she could see the almost child-like face of the lieutenant. Perhaps she saw in it her own reflection, something like the pain hidden deep in her heart, the persistent pain of a girl from a small town who has encountered life's weight in its most cruel manifestation, at war. (28)

The lieutenant brings out both the maternal and the child in her and without knowing it transforms the young woman into a better Soviet citizen. In Travkin, Katya sees someone so good, so pure, that she too becomes pure, despite having previously defined herself as an "experienced sinner" - not the appropriate heroine to match Travkin. With her new interest in being helpful, she now spends hours in his abode, trying to make his home "homier" and hoping that he will notice her.

Through contact with Lieutenant Travkin, Katya is transformed from fallen woman to Soviet mother-patriot. At one point in the narrative, frustrated that Travkin is deliberately ignoring her devotion to him, she thinks that she may go back to her previous ways with another, less lofty man. The narrator explains, "In Barashkin everything was ordinary, simple and clear, and that seemed to her now just what a person needed to be happy." But soon Katya realizes that "this 'ordinariness' was already foreign and disgusting to her" (43).

The ordinary is sex - taboo in Soviet literature-while the extraordinary is incorporeal, higher than mere sex and the body; indeed, it is exemplified by podvig, by feats, and personified in Travkin. As one Soviet critic has written, Katya's unrequited love for the lieutenant showed the "cleansing spiritual strength of Travkin, a fine man and warrior." ${ }^{\prime 4}$ The warrior-hero does more than defend his country; in Kazakevich's novella, he restores the virginity of Russia's women as well, making them fit to bear further sons for the motherland.

As we have discussed, successful war prose has two characteristics: these stories are filled with detail, to make them seem real, and they somehow

14 Gladkovskaia, “Emmanuil Kazakevich,” 10. 
transcend the details to make them true. That was certainly what socialist realist doctrine demanded: the "truthful, historically concrete representation of reality" plus "ideological transformation and education." Travkin does not change over the course of this novella, but the other characters who encounter him do. Not just Katya, but some of the soldiers in his unit as well are changed for the better, brought into the collective and made aware of their duty to their country through their contact with this quiet, understated, brave, and conscious hero.

\section{All for One: Unity and Conformity in The Star}

The Star was based on the author's own experience on reconnaissance duty during the war. In order to make meaning out of that experience, Kazakevich invented Travkin and his men. His narrator also generalizes, however, describing the work of the reconnaissance man in eternal terms. As he prepares for his mission:

The scout no longer belongs to himself, to his superiors, to his memories. [...] He renounces all human establishments, puts himself outside the law, relying only on himself. He gives his starshina all his documents, letters, photographs, awards and medals, to the party head-his party or Komsomol card. Thus he renounces his past and his future, keeping it all only in his heart. Like a forest bird, he has no name [...] in the depths of his brain holding dear only one thought: his mission. Thus began the ancient game, in which the only two actors were man and death. ${ }^{15}$

Like Tvardovsky, Kazakevich figures the struggle of the warrior as a confrontation between Man and Death, here presented as a classic duel. Even though the reconnaissance group in this story consists of seven people, they are a unit-a collective that acts as one, led by the intrepid Lieutenant Vladimir Travkin:

Again and again Travkin looked into his comrades' faces. These were no longer subordinates, but comrades; the life of each depended on all the rest, and he, the commander, felt them not as other people, different

15 Kazakevich, Zvezda, 46. Here, as in Tvardovskii's chapter "Duel” (Poedinok) the duel pits the Russian against the enemy: "Как на древнем поле боя, / Грудь на грудь, что щит на щит- / Вместо тысяч бьются двое, / Словно схватка все решит” (Tvardovskii, Vasilii Tyorkin, 81). 
from him, but as parts of his own body. [.. .] Travkin was satisfied with himself-with himself, multiplied by seven. ${ }^{16}$

"Himself multiplied by seven"-a perfect description of the way individuality could be melded into the larger collective.

Travkin's group is trapped behind enemy lines, and one by one the soldiers are wounded until they all perish. But to turn this sacrifice into a victorious feat, Kazakevich highlights the dueling hand of Death, which deals a blow against the Germans:

All these Germans-gobbling up food, bellowing, befouling the surrounding forests, all these Hilles, Mullenkamps, Gargasses, all these careerists and punishers, hangsmen and murderers-walk along the forest paths straight to their destruction, and death lowers onto all fifteen thousand of these heads her punishing hand. ${ }^{17}$

The punishers are punished; the division of fifteen thousand crack German SS troops are no match for the hand of Death, nor indeed for the seven-asone Soviet unit.

In The Star Travkin's death, somehow, does not matter. Like Vasily Tyorkin, who faded into the masses of soldiers at war's end, and like Chapaev whose body is lost forever to the river, Travkin's fate is never mentioned, but instead must be intuited through the sad and fruitless waiting of the "hero's fiancée," the radio operator Katya. The star has "set and been extinguished." 18 Travkin does not return from the mission.

Like many Soviet war novels, this one ends with success: the mission is completed, and though the heroes may have perished, their victory lives on. This sacrifice is part of the trajectory of heroism, and it neatly avoids having to deal with the problem of what happens to heroes when they must return home to civilian life.

Kazakevich's narrative celebrates that collective spirit, that ability of a unit to join together, re-forming when one member is lost, and most importantly never questioning the leader. In that sense, Travkin's unit is a microcosm of the Soviet state itself, endlessly willing to follow its leader and endlessly able

16 Kazakevich, Zvezda, 55.

17 Ibid., 75.

18 Ibid., 80. 
to be replenished. Life on Earth (as the base camp is known in the novella's radio lingo) goes on, and though Travkin's unit vanishes, by the end of the narrative a new group of scouts takes its place and heads through Poland in the direction of Berlin and victory. ${ }^{19}$

Socialist realism wanted to have it both ways: to make the prose believable, authors should fill it with concrete details, but to make it inspiring, characters and actions needed to transform the reader, to raise him or her to the level of extraordinariness, of podvig. Kazakevich too tries to have it both ways, including details but also aiming at the universal, the transcendent. In presenting the struggle of the "fine warrior" as a duel, Kazakevich alters Tvardovsky's scene of the lonely warrior versus Death; Travkin is the leader of a band of scouts, pitted against a German tank division.

Kazakevich brings the narrative to a melodramatic conclusion as Katya realizes that Travkin is not responding to her repeated radio calls. Having informed his commanders of the secret concentration of the Fifth SS "Viking" Tank Division, the reconnaissance lieutenant perishes along with all of his men. "The circles around Travkin widened in waves along the surface of the earth: to Berlin itself and to Moscow itself" (78). His work has its effect, although he must sacrifice himself and all his men to attain it. Here too, requirements of socialist realist fiction affect the narrative; the hero is represented both by an individual, Travkin, and by the collective. And while death triumphs over Travkin, his heroic deed saves many. ${ }^{20}$

In a memoir, Kazakevich admitted that he was not particularly fond of the characters of The Star, in comparison to the fondness he held for some of his later characters. Nonetheless, Kazakevich believed in the concept of the positive hero. As he wrote:

He exists-you will be able to see him. This is a complicated man, intelligent, thinking, active, suffering as all men should whenever he sees failures, defects, when he encounters pockets of old-fashioned

19 For another recent interpretation of The Star, see Frank Ellis, The Damned and the Dead: The Eastern Front through the Eyes of Soviet and Russian Novelists (Lawrence: University of Kansas Press, 2011), 36-39.

20 On this, see L. N. Luzianina, "Dukhovnyi smysl kontsepta 'zvezda' v odnoimennoi povesti E. Kazakevicha," in Dukhovnost' kak antropologicheskaia universaliia v sovremennom literaturovedenii (Kirov: Izdatel'stvo Viatskogo gosudarstvennogo gumanitarnogo universiteta, 2009), 96-99. 
thinking but not giving up, ready to fight for communism; a lucid, fine, although perfectly ordinary man. ${ }^{21}$

This emphasis on the ordinary belies the wartime propaganda that existed alongside such heroes as Vasily Tyorkin and Volodya Travkin. Travkin is the "ideal hero, who 'teaches the art of victory."

As characters and soldiers, Travkin and Tyorkin-cheerful and willing to die without forethought, brave enough to lead the way into battle, across rivers, into woods teeming with enemy forces-must find their way between the capital- $H$ Hero embodied in the eighteenth-century general Alexander Suvorov, whose heroic image Stalin evoked in his famous November 7, 1941, speech but surely would not have welcomed in the theatre of battle, and the bravado-filled peasant-hero Vasily Chapaev, while simultaneously showing themselves to be both indispensable and utterly replaceable. In the words of a poet of the time:

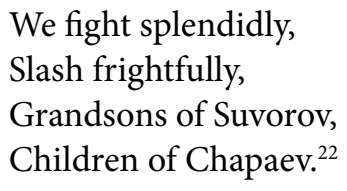

Descendents and comrades, indispensable and replaceable. These ironies of the socialist realist canon, and its positive heroes, complicated the idea of the military hero in wartime as well as in war fiction.

\section{A Woman's War: Vera Panova's The Train Companions}

But it was not only men who faced contradictions real and fictional during the Second World War. Women too were central to the war effort and found themselves in roles previously reserved for men. The films made in the early years of the war depicted the many women mobilized as nurses, soldiers, and journalists as well as those who became partisans. ${ }^{23}$

21 Qtd. in A. Kudriashova, “Kakoi ty, chelovek,” Voprosy literatury 7 (1965): 203.

22 Quoted in Shtut, Kakoi ty, Chelovek?, 157.

23 Denise Youngblood, "Ivan's Childhood and Come and See: Post-Stalinist Cinema and the Myth of World War II," in World War II, Film and History, ed. John Whiteclay Chambers II and David Culbert (New York and Oxford: Oxford University Press, 1996), 85-96, 86. In the 1980s journalist Svetlana Aleksievich explores this very question: what does a "female war" look like, as compared to the "male war" of statistics, sacrifice, and podvig? See Aleksievich, $U$ voiny ne zhenskoe litso (Moscow: Vremia, 2007). See also Krylova, Soviet Women in Combat. 
Kazakevich confronted this situation and presented one solution to it in the character of Katya and her unrequited crush on Travkin. Katya plays a real role in the war effort, in uniform and engaged directly in the work of reconnaissance and battle. But Kazakevich insists on her femininity, on her yearning for Travkin's love, and on her maternal impulses. Her redemption is not through the higher consciousness of the Soviet collective but through her return to the old-fashioned conventions of female behavior.

War, it turns out, can be a "plastic juncture" for women too, opening up new opportunities for danger, fulfillment, and heroism. In order to keep them from taking too much advantage of that moment, Soviet women in uniform were presented as martial and feminine at the same time.

Among the many women who experienced the war, Vera Panova stands as one of the few who published significantly about it. In her novella The Train Companions (Sputniki, sometimes translated as The Train), Panova portrayed political and medical workers on a hospital train equipped to treat and evacuate war-injured soldiers and civilians.

Though the novel was and remains popular, Panova's work has had a mixed reception from critics over the years. Some of the critique may stem from the fact that the novella won a Stalin Prize in 1947. Catriona Kelly, for example, lumps Panova and her fiction in with writers of socialist realist "kitsch," the term she uses to describe popular literature of the 1940s. Kelly surmises that

these texts seemed an irritating and even disgusting irrelevance to some readers who had an idea of the realities of the Terror. But for many others they probably functioned as an uplifting or consoling vision of a Socialist utopia just round the corner, or as a wish-fulfilling fantasy of a normal, decent life without stress or hardship, a vital counterbalance to the exigencies of actuality. ${ }^{24}$

24 Catriona Kelly, A History of Russian Women's Writing, 1880-1992 (Oxford: Clarendon Press, 1994), 252-253. See also Edward J. Brown, Russian Literature since the Revolution (London: Collier-Macmillan, 1969), 243 and Ruth Kreutzer, who complains that Panova never wrote a fictional work about her husband Boris Vakhtin, who was arrested and ultimately executed during the mid-1930s (Kreutzer, "Vera Panova," in Russian Women Writers, ed. Christine Tomei [New York: Garland Publishing, 1999] 1019). Panova did write about the horrors of Vakhtin's arrest, imprisonment on Solovki, and second sentence in her memoirs, first published in 1989. See Vera Panova, Moe i tol'ko moe: o moei zhizni, knigakh, i chitateliakh (St. Petersburg: Izdatel'stvo zhurnala Zvezda, 2005), 144-178. 
Given that Panova herself was a victim of the Terror, this characterization seems overly dismissive both of her biography and of what she was trying to do with her fiction. Other complaints seem to grow out of the uneasiness a woman writing about war caused for male readers and critics. But the 1940s and '50s in particular were a complex time period in the world of Soviet literature and publishing, and it is possible to take a different approach with more sympathy for the kinds of literature Panova was producing, especially considering Panova's negotiation of her own personal and political biography at the time.

Even before becoming a participant in the war effort, Panova lived the tension between the feminine and the martial. In the purges of 1935 and 1937, her beloved second husband, Boris Vakhtin, had been arrested and exiled to a Siberian prison camp. ${ }^{25}$ When Panova was fired from her job at a newspaper because she had now become the wife of an "enemy of the people," she faced real economic problems. As the war loomed, Panova found herself the sole provider for four dependents: two young sons, an older daughter, and her mother.

Panova also exemplifies the complications for Soviet citizens caused by the Soviet war effort following on the heels of the Stalinist purges. Fearing arrest by agents of her own government as an "enemy of the people" herself, she was living near Leningrad in an area that was quickly occupied by the Nazi army near the beginning of the war. She survived the bombing of the area and was nearly conscripted by the Nazis into a work camp. In the midst of all this, the writer managed to make a career and write honest books and plays-no inconsiderable feat.

Indeed, she gets credit from scholar Beth Holmgren as more than just another Stalin-prize-winning novelist for her "key role in precipitating the intermittent thaw in Soviet literature, advocating and demonstrating a greater emphasis on sincerity and emotional expression in [her] work." Holmgren

25 In her memoirs, Panova describes not knowing her husband's fate. "Later I was told that in 1937 all political prisoners were judged a second time and the formula of the sentence I had been given meant, essentially, execution; the camps were being purged to make room for new victims. I don't know whether this was true, but in 1958, when my Buvochka was fully rehabilitated, the paper read 'rehabilitated posthumously.' I don't know if he died from an illness, or in the torture chamber, like [the former Party worker and our acquaintance] Yakov Fal'kner, or whether he really was shot at that time" (Panova, Moe i tol'ko moe, 178). 
praises Panova's domestication of space and characters in the war narrative The Train Companions, arguing that

the main setting of a hospital train already indicates the move from "masculine" battlefield to a site of human repair and recuperation. The occupants of this gleaming state-of-the-art facility labor to make it a self-sufficient "home," taking on livestock and attaching dust ruffles to the lamps.

This effort, Holmgren argues, launched the process of "writing the female body politic," that is to say, chronicling the contributions women made to postwar Soviet society and clearing a space for women in what has otherwise always been a male sphere. ${ }^{26}$ Among other things, women in Panova's fiction-even in The Train Companions, with its wartime setting-read books, go to the beauty salon and the movies, and negotiate the boundaries between personal and public life, including everything from fantasies of love and motherhood to efficient workplace behavior.

\section{Wartime Work in Perpetual Motion}

In December of 1944, Vera Panova left her Perm newspaper (called, coincidentally, The Star) and began her life on a military hospital train, where she was charged with the task of writing about the train for a Sanitary Bureau brochure. The experience of train travel in wartime sharpened the experience of war itself. Both aspects of war-waiting around endlessly and being thrown into frenetic activity-are present in this experience and traumatize the passenger just as they do the soldier in the trenches: the long, unnerving waiting and preparing for action and the sudden, overwhelming, and all-consuming activity of dealing with wounded and dying soldiers and civilians. On the one hand, a journey, living and travelling in the train along railroad tracks that had been laid many decades before. On the other hand, the opposite of a journey. As Panova recalled some years later:

Here the route can change at any moment, and no one knows how many months and years your trip will last (about days it's not worth

26 Beth Holmgren, "Writing the Female Body Politic (1945-1985)," in A History of Women's Writing in Russia, ed. Adele Marie Barker and Jehanne M. Gheith (Cambridge: Cambridge University Press, 2002), 226, 231. See also Krylova, "Soviet Women Writers and the Search for Self," in the same volume, 243-263, esp. 245-246. 
speaking); both the trip and time disappear like the soil beneath your feet.

It's exhausting to rattle around thus in time and space. $[\ldots]$

The people with whom fate united me lived that way for more than four years: military-hospital train number 312 was formed in July 1941 and dispersed in October 1945. People who were always travelling; at the same time always fixed in one place; not belonging to themselves; losing any sense of time,- - such people had to exert an immense amount of effort in order not to lose their equilibrium. They were aided by work. ${ }^{27}$

Panova describes the situation as a kind of work therapy; in the midst of war, blood, and personal tragedy, the work kept her companions sane.

As Panova relates the conditions in this particular hospital train (and metonymically in wartime itself) she focuses almost entirely on the collective. In fact, her fictional train functions as an ideal work collective, and none of the characters on it assume the role of heroic individual. The very cleanliness of the train was for her a metaphor:

Such cleanliness was perfectly matched to the general spirit of train life: a spirit of decorousness. I did not hear shouting, arguing, rowdy conversations. Everyone was busy with work, filled with dignity. They interacted respectfully. My friends, how wonderful it was, noble and healing. If people would only want it, things could essentially be this way in any place of work. ... (“'Otkuda vzialas'," 336)

Sent as a journalist on assignment, Panova felt compelled to start a novel:

I'll write down the stories I hear, I'll write it in their words-the story of the female orderly, the story of the doctor, the soldier, the nurse-and the voices of living people, their intonations, will ring out. The book will be read everywhere, and not just at the Main Sanitary Bureau." (“Otkuda vzialas'," 341)

27 Vera Panova, “Otkuda vzialias' kniga Sputniki," in Sputniki (Leningrad: Sovetskii pisatel', 1967), 337, 338. 
The novel would resemble an ensemble play, highlighting a number of the people whom she had interviewed. Panova's individual initiative did not go over well with the train's party organizer, but she persisted, stealing hours late at night to record her wartime experiences in something other than strict journalistic prose. Although Panova spent the war working for radio and newspapers as a journalist, her experience with the military hospital train gave her the start she needed in literature, a start almost stereotypically female, as she carved out time from her personal life to devote to her writing.

Panova continued writing the novel during 1945, mixing the voices, events, and people from Train \#312 with other people and events as she created her characters. In great part the structure of the novel emerged from the research itself. As she describes it, Panova sat in a compartment in the pharmacy car and interviewed the staff of the hospital train one by one:

My work day began at eight thirty.

People came one at a time, and each told about himself, about the train, the war, his own losses and hopes.

The captain sent them. Although unschooled in the subtleties of our profession, he chose the order of visits with a remarkable instinct, organizing them so that sparks flew from the combination of various tales, characters, and features, illuminating from new points of view the story that was building in my imagination. [ . . . ]

They all needed a listener. They had already told each other everything long ago, but here was a fresh person, silent, attentive. I didn't interrupt, didn't counter: "And here's what happened to me," only listened. And they could talk an hour, two hours, as much as they liked.

They laughed recalling funny events and cried remembering their dead. Fiancées spoke of their betrothed, husbands about their wives. Some sang me their favorite songs and romances. The Sanitary Bureau needed my pen, but these people needed my ears. ${ }^{28}$

Having over the course of several months travelled with the train twice to pick up the wounded and return them to the rear, she came to believe that literature was her métier: "I will be a writer because I cannot not become

28 Panova, “Otkuda vzialias' kniga Sputniki," 339. 
one; I cannot not tell the story of these people's feats. I will tell it as I see and understand it. This will be my own contribution to literature and life." ${ }^{29} \mathrm{Her}$ novel mirrored the "official" work she was doing, the brochure that entered the Museum of Medical Defense in Moscow-along with two of the wagons from Hospital Train \#312-when the war was over.

In her fictional train, Panova describes stops and starts, social interactions, constant repairs, and enterprising moneymaking ventures undertaken by some. The train becomes a microcosm of Soviet society, up to and including village life. Part of the train is given over to piglets, which the cook feeds with table scraps, and at one point they even obtain a few dozen chickens in order to have fresh eggs (Sputniki, 141-142). Panova's gentle, intelligent Dr. Belov describes the train as a rolling substitute for the homes everyone had left: "The train became overgrown with byt, it became a residence, a home, a household" (Sputniki, 189). Those details of everyday life, of byt, transform the space of the train-devoted to its military mission-into a real place, to which readers could relate regardless of whether they spent the war at the front or in the rear. The byt celebrated in Panova's novel humanized the rhetoric of $e s t^{\prime}$, the duty-bound, practical attitude of many during the Second World War.

The narrative effectively presents the bifurcated life of military personnel: waiting and preparing and even just killing time, followed by "loading time." Panova describes the difference on the level of personal energy, sounds, and even smells:

And then noisily, with babble and groans and the knocking of crutches, the War would enter into the wagon-wards, where each wrinkle had been lovingly ironed out of the sheets. Suddenly tobacco smoke began to curl toward the ceilings in dozens of streams. The blankets got bunched up, the pillows were off-kilter. The scents of disinfectants were driven away by the smell of pus, sweat, and heavy male breath.... A trip with patients was beginning. (Sputniki, 142, 143)

This was the rhythm of the train: empty cars in one direction and cars filled with filthy, broken, damaged soldiers in the other direction. Porózhny reis, gruzhyony reis. A rhyming rhythm in iambic tetrameter. According to

29 Panova, Moe i tol'ko moe, 275. 
Panova, it is that motion and the metronome-like alternation of sounds and smells that make up life, particularly the bifurcated life lived in wartime: disinfectant battling with infections, tidy supplies upset by the disorder of the patient-passengers. Her train presents a perfect example of Joseph Brodsky's observation that the details and the tragedy go side-by-side in Soviet war prose. ${ }^{30}$

\section{Individuals within the Collective: Companions on the Train}

Panova avoids the rhetoric of podvig altogether-despite her statement that she was recording "these people's feats"-and resists any attempt to turn ordinary wartime tragedy into the stuff of heroics. For example, when Dr. Belov receives news that his wife and daughter have perished in the blockade of Leningrad, he can barely function. "He was afraid that he would forever forget how to minister to the sick, to think, to read. The world had receded from him, lost its sounds, its smells, its tangibility" (Sputniki, 195). This approach, an understated portrayal of suffering that remains outside the narrative, marks Panova's specific "antiheroism."

Of one eighteen-year-old soldier, Panova writes, "What feats he had achieved, he couldn't really say. He ran, he shot. He crawled, he shot. He sat, he shot. He had a vague understanding of tactics. He had understood his primary function well and he fulfilled it well, so his stories and medals attested" (Sputniki, 159). The simplicity of war on an individual level is reduced to this: the boy shooting whenever he could, the wife and daughter perishing in a bomb attack while the doctor, helpless and out of touch, continues to send packages and wait for letters. What other writers might have portrayed as glorious here has no particular glory. Panova neither moralizes nor wallows in the suffering of her characters; she merely relates their fates and gives them voice.

One of the women central to the story is Lena Ogorodnikova, an orphan who has made her own Soviet happiness. Lena works cheerfully through the entire war in honor of her husband, Dania. Her own clarity about her

30 Joseph Brodsky has commented that "in terms of intensity of sentiment, in terms of horrendousness of detail, in terms of hopelessness of the individual's predicament in the course of that war, Russian war prose ... stands to win hands down [...], stay[ing] palpably close to the immediacy of individual tragedy" ("Literature and War: A Symposium. The Soviet Union," Times Literary Supplement 17 May, 1985: 543-544). Poetry, Brodsky argues, does a "far more universal job" of chronicling tragedy. 
family life, replacing the absent parents with the beloved husband, makes her whole and enables her to tend to patients, to clean and care for them and for the train. Only at the end of the novella is Lena's happiness snatched away from her: it turns out that Dania has found another. "The love that had given her strength, beauty, and happiness now weighed upon her shoulders like a heavy cross" (Sputniki, 290). Panova's narrator pities Ogorodnikova, but her fate mirrors a common outcome for a soldier's wife: the end of her marriage through infidelity. The personal "garden" she tended-as her name suggests-has been violated, but her service throughout the war to the unknown patients makes her a valued member of the collective, a loyal "train companion."

A second woman character, the surgical nurse Iuliia Dmitrievna, represents a clear contrast, tied as she is to duty and byt. Fully engrossed in her work, Iuliia Dmitrievna dreams of love only in the abstract. Her matter-offact attitude keeps the patients moving along, and there is no room for the personal. When near the end of the novella she thinks perhaps marriage awaits her with Dr. Suprugov (whose name, related to the word "spouse," belies his status as a confirmed bachelor), she is mistaken. Instead Panova gives her a child, the thirteen-year-old Vaska, who becomes her apprentice (Sputniki, 259-261). Here too the hospital train mirrors the outside world, with its orphaned children set adrift and seeking homes, and lonely women settling for any kind of familial arrangement they can find.

In her real wartime experiences, Panova thought of her political commissar as the "soul" of the train, and in the novel, she embodies him in the character of Danilov. Flashbacks to Danilov's childhood show that he might have featured as a war hero; he inherited a love of hard work from his father, a devout blacksmith, and learned to care for himself from his mother, who always said, teaching him to sew on buttons or wash his clothes, "It will come in handy when you're a soldier" (Sputniki, 206). As if to make the point of what a conventional soldier looks like, Danilov and the entire train staff go off to the movies while the train is stopped, and there they see a newsreel and a feature, both about the war:

The hero was a young man, as good-looking as on a poster, and his girl was the same. They accomplished feats (sovershali podvigi) and then the girl was caught by the Fascists and died while being tortured by the butchers. Everyone understood that the fascists on the screen were not 
real, but it was all so timely and imminent-the feats, the hatred for the fascists, the good girl giving her life for her country-that they all became agitated while watching the film. ${ }^{31}$

In the official narrative of war, there is no place for love, and in Panova's story too Danilov recalls his own first love (Faina, who will shortly die in their hospital train, unrecognized by him until after her death), but he demonstratively has put love out of his mind. Instead he married coldly, because it was the right thing to do, and loved only the son his wife produced.

$\mathrm{He}$, the father, was creating the life in which his child would live freely and well. In order for the sons to live their lives along a light and smooth road, they, the fathers, were prepared to pave that road with their own bodies. That's how it was. (Sputniki, 226)

Danilov does not perish at the end of the novella, as so many Soviet heroes do, perhaps because he is the political officer, what before 1942 would have been called a commissar. His desire to "pave the road with his body" mirrors the idea of podvig in the Soviet war discourse, of sacrifice for future generations. But his role in Panova's novella as political officer rather than military hero means that he will survive.

Moving back and forth between military and civilian life, Panova creates with her train companions a model for life in the postwar era. Her hospital train features a work collective that actually functions, and her characters are no less important to the war than Kazakevich's scouts, but they don't have to perish in the end. Just as women in wartime had to negotiate the martial and the feminine, these characters domesticated the space of the train and found ways to execute their military duties while continuing to experience human emotions and human problems. This is what awaited the survivors of World War II: disabled bodies, broken families, personal betrayal, and the need to rebuild once again.

Demobilized soldiers and their civilian counterparts immediately after the war needed inspiration, but not the false inspiration that had rung out in official propaganda and in the poetry of hatred. They wanted to read about little men and women like themselves, individuals who tried to take heroic

31 Panova, Sputniki, 203. The frequency with which watching war films forms part of the plot of war novels is fascinating and worth further exploration. 
steps, and occasionally made errors, in the daily struggles of fighting for the common good and the Soviet motherland. Both Kazakevich and Panova gave them those individuals in the midst of their byt. But in their work, they emphasized the importance of the collective in achieving the feats of victory and the satisfaction of duty, the podvig and the est', during World War II. Cognizant of the censorship their work would undergo, these writers strove to find the most expressive ways of chronicling the war while still getting their narratives published, of taking their personal experiences and the actions they witnessed and turning them into literature that mattered and that would reach their readers.

American writer Tim O'Brien, in trying to define what a "true war story" is, explains:

You can tell a true war story by the questions you ask. Somebody tells a story, let's say, and afterward you ask, "Is it true?" and if the answer matters, you've got your answer.

For example, we've all heard this one. Four guys go down a trail. A grenade sails out. One guy jumps on it and takes the blast and saves his three buddies.

Is it true?

The answer matters.

O'Brien's story comes straight out of Vietnam, but it certainly rings in the Soviet experience-the individual selflessly sacrificing himself for the sake of the group. Chapaev perished, and the Red Army was victorious. Tyorkin neared death repeatedly, and the Nazis were vanquished in part because of peasant-soldiers like him who kept at their wartime tasks despite the grim conditions and carnage around them. But O'Brien goes on to discuss the risks of such storytelling:

You'd feel cheated if it never happened. Without the grounding reality, it's just a trite bit of puffery, pure Hollywood, untrue in the way all such stories are untrue. Yet even if it did happen-and maybe it did, anything's possible-even then you know it can't be true, because a true war story does not depend upon that kind of truth. Absolute 
occurrence is irrelevant. A thing may happen and be a total lie; another thing may not happen and be truer than the truth. For example: Four guys go down a trail. A grenade sails out. One guy jumps on it and takes the blast, but it's a killer grenade and everybody dies anyway. Before they die, though, one of the dead guys says, "The fuck you do that for?" and the jumper says, "Story of my life, man," and the other guy starts to smile but he's dead. That's a true story that never happened. (Things They Carried, 83-84)

True stories. Myths. Readers can sometimes tell the difference. Tim O'Brien suggests that irony is at the core of a true story; heroism is less likely to be true, even if we want it to be.

Thinking about O'Brien and his war stories from Vietnam provides a useful way of thinking about the ideologically driven, detail-oriented stories of Soviet World War II heroism. After all, if soldiers, eyewitnesses, and journalists turned the details of real experiences into larger works of fiction, then we ought to remember that the traffic can go both ways. Fictional expectations can structure the way "reality" was perceived and reported.

One such case, the famous story of the twenty-eight Panfilov heroes who perished in a fight with fifty-four German tanks on November 16, 1941, was proven to be utterly fabricated. The investigation is detailed in a secret document dating to 1948. Hints of the results surfaced in 1966, but they were quickly suppressed, and the story finally began to emerge during perestroika, with the full 1948 document published in Novyi Mir in 1997.32 This story-the mythic tale of the heroes, the ways in which the Soviet state and society embraced their heroic feats, and the narrative of how the tale was constructed, how it was discovered, covered up, and rediscovered-can teach us much about war journalism, patriotism, state control, and the relationship between truth and myth, and it is worth relating the story here.

In November of 1941-a time of particularly bad tidings for the Soviet Red Army-a regiment of the Panfilov Division faced an overwhelming attack from German tanks. A correspondent of the Red Army newspaper Krasnaya Zvezda, Koroteev, published a small article on November 27 about the battle, taking his information from a commissar of the division who had

32 See N. Petrov and O. Edel'man, "Novoe o sovetskikh geroiakh," Novyi mir 6 (1997): 140-151. 
himself not participated in the battle, but who wanted the correspondent to know about the "extremely difficult situation at the front." 33

These are the facts. But what happened from there was pure invention. The editor of Krasnaya Zvezda was Major General Ortenberg-the same editor who serialized Vasily Grossman's The Immortal People from July 14 to August 12, 1942 34 and he argued in 1948 that

the question of Soviet warriors' steadfastness was particularly important at that time. The slogan "Death or Victory," especially in struggles with enemy tanks, was a decisive one. The feats (podvigi) of the Panfilov [soldiers] were a model of precisely that kind of steadfastness. I proposed to Krivitsky that he write a lead article about the heroism of the Panfilov [soldiers], and we published it in the newspaper on November 28, $1941 .{ }^{35}$

Thus eight months before Stalin's famous "Not One Step Backward" speech of July 28, 1942, newspaper editors and correspondents were already working to create a culture of podvig, a culture of self-sacrificing heroism, through manipulating stories of the front. Ortenburg and others like him saw this as their patriotic duty, their contribution to the war effort; instead of shooting the enemy or mining fields at the front, they used their literary positions to help fight the war against the Germans.

This "invention," as Lieutenant General N. Afanasiev, the head military procurator of the USSR Military Forces, styled the myth of the twenty-eight Panfilov soldiers in his May 10, 1948, report, succeeded in great part for the same reason that the fictional texts we looked at above succeeded: the details made the story. If the story was entirely made up (and it was, by numerous sources in a kind of collective process on its way to becoming a foundational myth of Soviet heroism), why twenty-eight soldiers? Does the answer matter?

It turns out that when asked how many people are usually in a regiment, the original war correspondent replied, "Thirty to forty, but the unit was not at full strength." Thus the number chosen was thirty, but the original storyfrom the commissar-included two soldiers who surrendered, hands up, to

33 From the evidence by Koroteev, in "Novoe o sovetskikh geroiakh," 147.

34 See Grossman, A Writer at War, 114.

35 From the evidence by Ortenburg, in "Novoe o sovetskikh geroiakh," 148. 
the Germans. Thus $30-2=28$. Then Ortenberg nixed the two traitors, arguing that one was plenty, ${ }^{36}$ but he didn't nix the math. $40-10=30-2=28$. But really twenty-nine.

Another key detail of Krivitsky's second newspaper story was the words of political instructor Klochkov: "Russia is great, and there's nowhere to retreat-Moscow is behind us," a phrase that could under no circumstances have been legitimately "reported speech" (after all, the Panfilovtsy died). Krivitsky testified, "I made it up myself." ${ }^{37}$ This slogan (great in the telling, unlikely in the trenches) was repeated again and again in story, song, and film in staging the Panfilov tale. But Krivitsky willingly gave evidence to say that "as far as the sensations and actions of the 28 heroes-that was my literary invention." ${ }^{38}$ In his article, Krivitsky named names and reported details, and that too contributed to the "real" quality of the reportage:

Let the army and the country finally know their proud names. In the trench were: Klochkov Vasily Georgievich, Dobrobabin Ivan Evstafevich, Shepetkov Ivan Alekseevich, Kriuchkov Abram Ivanovich, Mitin Gavriil Stepanovich. ... ${ }^{39}$

And so on. ${ }^{40}$

Soldiers with brave retorts and real names and patronymics. Details and dialogue. These elements helped create a myth that lived on through perestroika and was finally uncovered for the broad public in the late 1990s. Was it a true story, according to O'Brien's criteria? For certain segments of the population, those myths continue to be as dear as ever, their need to believe in the "truth" of Stalin-era Russia and the success of the ideological condi-

36 “Ortenburg said that it's impossible to write about two traitors, and, apparently having conferred with someone, decided to write about only one traitor in the lead article" (From the evidence by Koroteev, "Novoe o sovetskikh geroiakh," 147).

37 From the evidence by Krivitsky, "Novoe o sovetskikh geroiakh," 147.

38 Ibid., 147-148.

39 Ibid., 144-145.

40 It became awkward when one of those honored posthumously with the title "Hero of the Soviet Union" returned from German captivity . . but in true Soviet style that offending physical body - a physical body that contradicted a dearly held myth - was quickly swept off to the camps until the mid-'50s. He was later refused rehabilitation and the rights to his title when he emerged from prison, and was even accused in 1990 (now truly posthumously) of trying to horn in on "others' fame" ["Chuzhaia slava"] in calling himself (a Red Army soldier who had actually worn a German uniform, after all) a Panfilovets. Ibid., 150. 
tioning they underwent during that time superseding their own instincts as readers. ${ }^{41}$ Indeed, Lebedev's 2002 film remake of The Star reifies just this myth of the brave, self-sacrificing Red Army man, exemplifying what Mark Lipovetsky has called "the Soviet myth of war [as] adopted by the post-Soviet rhetoric of national identity" ${ }^{42}$ It seems that new generations are buying the Soviet ideological myth of the sacrificial warrior. But for O'Brien, the moral that is required of all Soviet narratives would definitely ring false. As we investigate issues of "truth" and "invention," truth and myth, their genesis and their role in the Soviet understanding of World War II, it is worth keeping O'Brien's categories and the Panfilovtsy themselves in mind. The "realism" portion of socialist realism required details, and wartime is full of details, ready to be noticed and narrativized by writers and journalists. Twenty-eight men sacrificing themselves felt real, but perhaps not as real as Panova's piglets on a train.

41 Nina Wieda writes about this as "secular kenosis" and sees the sacrifice of Russian/ Soviet military men as mirroring the Christian paradigm of sacrifice. See her unpublished paper “Secular Kenosis in Boris Vasil'ev's And Dawns Are Quiet Here," ASEEES 2010, Los Angeles, CA.

42 Mark Lipovetsky, "War as the Family Value: Failing Fathers and Monstrous Sons in My Stepbrother Frankenstein," in Cinepaternity: Fathers and Sons in Soviet and PostSoviet Film, ed. Helena Goscilo and Yana Hashamova (Bloomington: Indiana University Press, 2010), 114-137, 133. Lebedev's remake tells us much more about the Putin era and its love of militaristic patriotism than about World War II. 